\title{
Litter Mass and Nutrient Dynamics in a Transformed Rainforest Ecosystem in Southwestern Nigeria
}

\author{
A. F Ojo ${ }^{\text {a }}$ T. O. S. Kadeba ${ }^{\mathrm{b}}$ and J. Kayode ${ }^{\mathrm{c}}$ \\ ${ }^{a}$ Dept. of Afforestation, Ministry of Lands, Housing and Environment, Ado - Ekiti, Nigeria, ${ }^{b}$ Dept. of Forestry and \\ Wood Technology, Federal University of Technology, Akure, Nigeria and ${ }^{c}$ Dept. of Plant Science, University of \\ Ado-Ekiti, Ado-Ekiti, Nigeria.
}

\begin{abstract}
Litter mass and nutrient changes were studied in a tropical rainforest after the original vegetation was converted to a monoculture plantation of teak. (Tectona grandis Lim.) in Akure forest reserve in southwestern Nigeria. The amount of litter and macronutrients $\mathrm{N}$, P, K, Ca

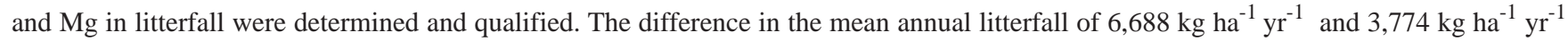
for the natural forest and plantation respectively are in the ratio 2:1. The mean monthly litterfall was statistically significant at 5\% probability level. Except for N, nutrient recycling from litterfall showed no significant difference between the two ecosystems. The relative content of the nutrient elements in the litterfall were in the order $\mathrm{Ca}>\mathrm{Mg}>\mathrm{K}>\mathrm{N}>\mathrm{P}$ in the plantation. Result showed that even though there was lot in litterfall as a result of the conversion, such was not enough to adversely affect the nutrient level of litter and overall litter nutrient contribution to the ecosystem.
\end{abstract}

Key words: Teak, Litter mass, Macronutrients and Tropical rainforest

\section{Introduction}

Litterfall is an important aspect of the plant nutrient recycling process. Its production and subsequent decomposition play a major role in the transfer of energy and nutrient in forest ecosystems (Songwe, 1984) especially in the tropics where most of the recycling nutrient depends on the amount of litter on the forest floor. Such litter is capable of adding large organic materials to the soil (Oguche, 2002). Subsequent decomposition of such organic materials and the resultant nutrient release strongly influence both the physical and chemical properties of the soil (Upadhay and Singh, 1989). Apart from the major role of litter in nutrient accumulation and recycling, it has also been recognized that litter cover plays a significant role in the germination of fallen fruit. Hence, it aids natural regeneration of forests and woodlands (Shaw, 1968).

Litter production in any ecosystem depends on some factors. These include the climatic condition of the ecosystem, the forest type, species composition, the age of the forest and plantation and method of conversion of the original forest to plantation (O Connell and Sankaran, 1997). Nutrient release to plants from litter is the first step in the recycling process within the ecosystem. Effective recycling of nutrient

\footnotetext{
* Corresponding author: E-mail: jokayode@ymail.com
}

enhances soil fertility (Okeke and Omaliko, 1992). The amount of nutrient released to the soil from litter is however influenced by the factors of the physical environment, the resource (litter) quality and the litter decomposer community (Swift and Anderson 1989).

This study is therefore designed to examine the changes in the amount and pattern of litterfall, the nutrient and the relationship between the two as a result of such ecosystem modification.

\section{Materials and Method}

The study was conducted in the Permanent Sample Plot, PSP No. 29 strictly reserved for research purpose by the Forestry Research Institute of Nigeria (FRIN) Ibadan, Nigeria and the adjacent 16 - year old teak plantation owned by the Ondo State Government in the forest reserve. The area lies along latitude $7^{0} 18^{1} \mathrm{~N}$ and longitude $5^{\circ} 02^{1} \mathrm{E}$ (Jones, 1948) and on an attitude of $250 \mathrm{~m}$ above the sea level (Fagbenro and Onweluzo, 1976, Ola - Adams and Hall, 1987). The climate is humid tropical (Thornthwaite, 1948) with seasonal variation. The mean annual rainfall is about $1,500 \mathrm{~mm}$ with 
double maxima in the months of July and September, and short relatively dry period in August. The relative humidity at 15 hours GMT is highest in the maxima months and lowest in February at about 81 and 44 percent respectively (Fagbenro et al; 1976). Temperature ranges from about $20.6^{\circ}$ $\mathrm{C}$ to $33.5^{\circ} \mathrm{C}$. The monthly mean temperature is about $27^{\circ} \mathrm{C}$, a condition that is conductive to the development of the tropical rainforests and plantations. The vegetation is lowland rainforest.

The area is gently undulating and plain. The underlying rock, which is gneiss, is crystalline as found in the basement complex. As a result of continuous weathering, the ferruginous (ferric luvisol) tropical soils which feature prominently in many upland parts of southwestern Nigeria is also present in Akure forest reserve (FAO/UNESCO, 1977).

\section{Laying of plots}

Two experimental sites representing two contrasting ecosystems (natural rainforest and teak plantation), but with similar soil and site conditions were selected adjacent to each other on a level (slope less than 5\%) land at the southern end of Akure forest reserve. In each of the ecosystems, a study plot, 0.25 ha (50 m x $50 \mathrm{~m}$ ) was demarcated. Each plot was further sub - divided into twenty five $10 \mathrm{~m}$ x $10 \mathrm{~m}$ sub - plots.

\section{Litter collection}

Litter was collected in $1 \mathrm{~m}$ x $0.5 \mathrm{~m} \times 0.15 \mathrm{~m}$ wooden trays covered with $2 \mathrm{~mm}$ fibre mesh at the bottom to allow for tree water drainage but not the smallest litter component in each sample plot of the moist natural forest and teak plantation. These trays were raised $0.75 \mathrm{~m}$ above the ground level to prevent contact with the forest floor. Ten trays were randomly distributed within each plot.

Litter was collected monthly for 24 months. Samples were taken to the laboratory, weighed, oven - dried at $70^{\circ} \mathrm{C}$ for 24 hours to remove moisture and bring all samples to constant weights. They were later reweighed. The oven - dried samples were then sealed in envelopes and stored.

Total annual litter collection were pooled together and divided into three composite samples for nutrient analysis. Samples of litter were oven - dried at $70^{\circ} \mathrm{C}$ for 24 hours for subsequent nutrient analysis for $\mathrm{N}, \mathrm{P}, \mathrm{K}, \mathrm{Ca}$ and $\mathrm{Mg}$.

\section{Litter Nutrient Analysis}

Litter tissues were separated into leaf, twig and the reproductive parts. Samples were further oven-dried at $70^{\circ} \mathrm{C}$ for 24 hours and ground in a Willey mill to pass through No. 40 mesh screen and then analysed for nutrient elements $\mathrm{N}, \mathrm{P}, \mathrm{K}$, $\mathrm{Ca}$ and $\mathrm{Mg}$.

(i) Total $\mathrm{N}$ samples were digested using the semi-microKjeldahl method and $\mathrm{N}$ was colorimetrically determined with the Technicon auti-analyser.

(ii) Extracts for the determination of $\mathrm{P}, \mathrm{K}, \mathrm{Ca}$ and $\mathrm{Mg}$ were prepared by wet digestion method using concentrated sulphuric acid, $\mathrm{H}_{2} \mathrm{SO}_{4} \mathrm{P}$ was determined calorimetrically, K by flame photometry while $\mathrm{Ca}$ and Mg concentrations were determined by atomic spectrophotometer.

\section{Statistical Analysis}

The student $t$ was employed to test the mean values of average monthly amount of litter and those of litter nutrients. Test of significance were carried out at 5\% and 1\% confidence levels.

\section{Results and Discussion}

\section{Amount and pattern of litterfall}

The natural forest had a higher litterfall than the plantation; but the litter had more variation in periodic distribution of its mass on annual and monthly basis (Figs. 1 and 2).

Annual variation occurred in the two ecosystems as 5,437 $\mathrm{kg} / \mathrm{ha}$ and 7,938 kg/ha of litter were recorded in the natural forest in the first and second years respectively while 4,292 $\mathrm{kg} / \mathrm{ha}$ and 3,055 kg/ha were recorded in the plantation within the same periods (Table I). Meanwhile, 6,688 kg/ha-1 $\mathrm{yr}^{-1}$ and $3,774 \mathrm{~kg} / \mathrm{ha}^{-1} \mathrm{yr}^{-1}$ were recorded in the natural forest and the teak plantation respectively on annual basis. These figures were statistically significant at 5\% probability level (Table II).

Peak litterfall occurred in the months of January and February in the natural forest (872 kg/ha or 13\%) while that of the plantation (578 kg/ha or 15\%) fall within December and January.

\section{Nutrient returns from litterfall}

\section{Nutrient concentration in litter components}

Concentration of $\mathrm{N}, \mathrm{P}, \mathrm{K}$, and $\mathrm{Mg}$ were low in the three parts-leaf, twig and the reproductive (flowers and fruits) parts, Ca was relatively more highly concentrated in the litter tissues in the two ecosystems (Table III). The leaf has the 


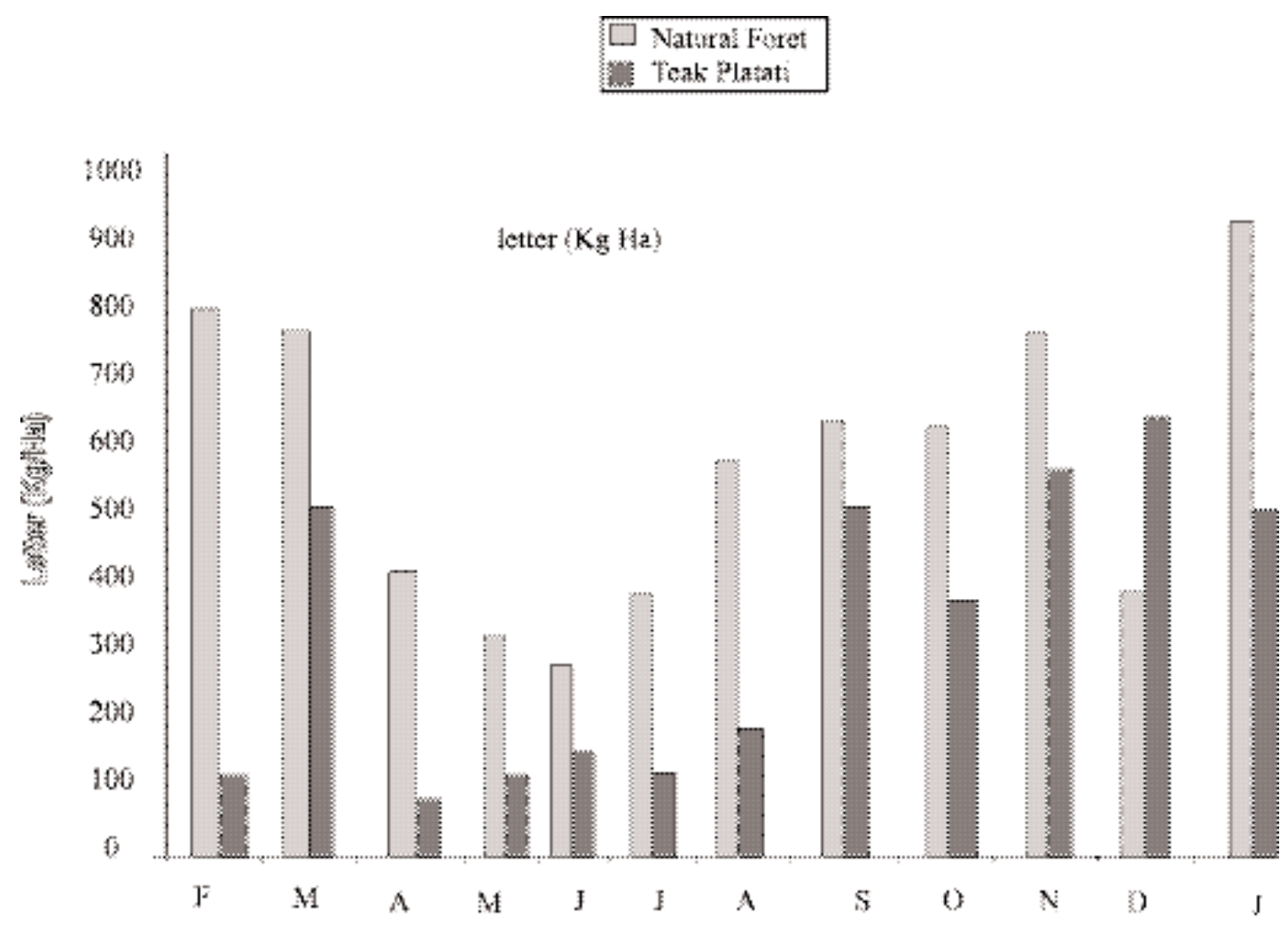

Mintiks

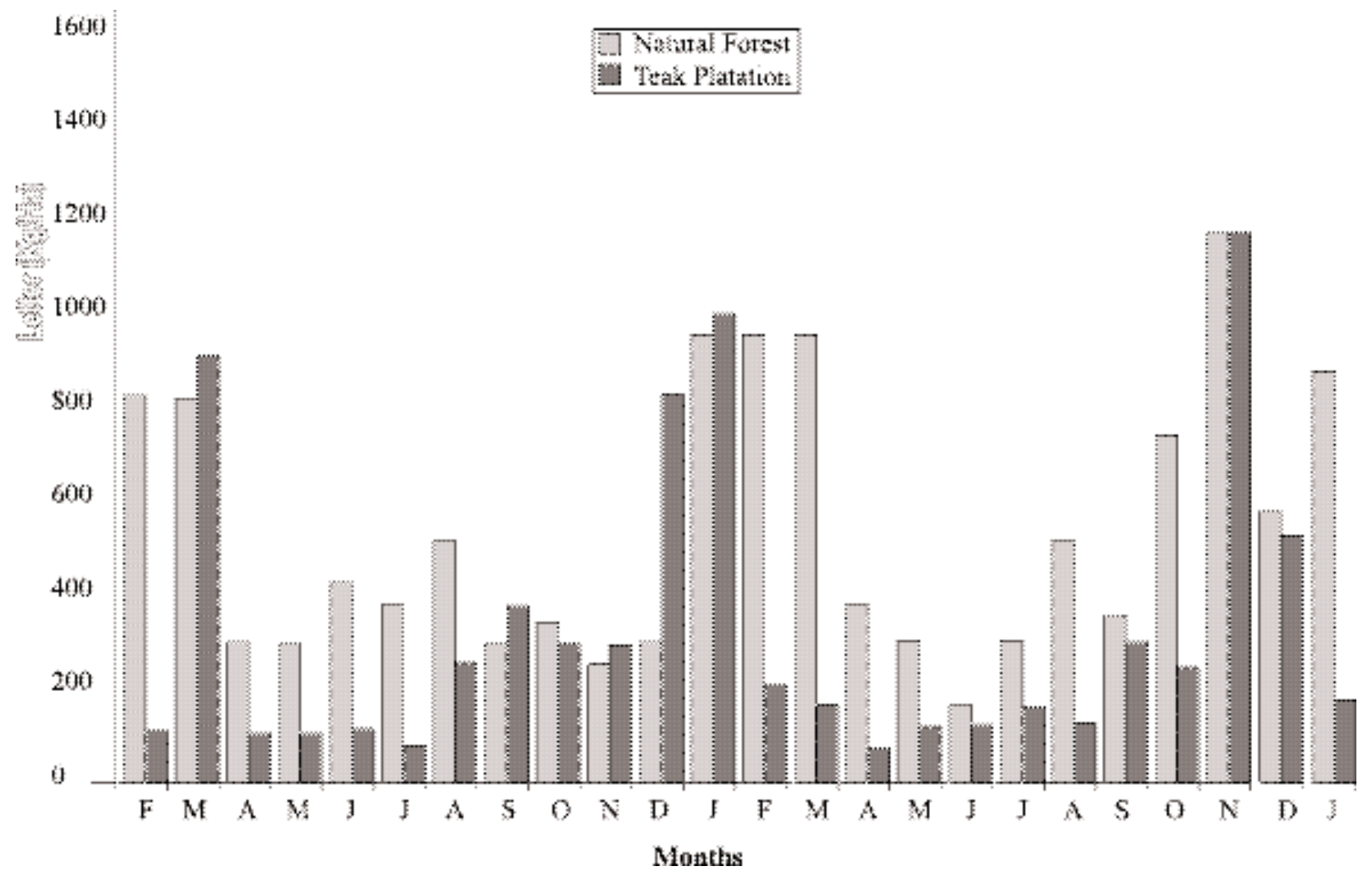

Fig. 1 and 2: Mean monthly litter collection in the natural forest and teak platation of Akure forest reserve 
Table I: Annual litterfall of the natural forest and 16- year teak plantation in Akure forest reserve

\begin{tabular}{l|c|c|c|c|c}
\hline Vegetation & \multicolumn{4}{c}{ Peak litterfall(kg/ha) } \\
\hline & year 1 & Year 2 & Mean $^{2}$ & Mean $^{3}$ & $\%$ \\
Natural forest & $5437 \pm 63^{1}$ & $7938+94$ & $6688 \pm 65$ & 872 & 13.0 \\
Teak plantation & $4292+82$ & $3055 \pm 63$ & $3774 \pm 60$ & 578 & 15.3 \\
\hline
\end{tabular}

1 = Standard error, 2 = Annual mean for the 2 - year period, 3 = Peak period mean

Table II: Compasion of means $(n=12)$ of biomass and nutrient content of monthly litterfall of the natural forest and teak plantation in Akure forest resreve

\begin{tabular}{l|c|c|c|c|c|c}
\hline Vegetation & \multicolumn{3}{|c|}{ Mean monthly litterfall } & \multicolumn{3}{c}{ Mean nutrient values (kg/ha) } \\
\hline \multirow{3}{*}{$\begin{array}{l}\text { Natural forest } \\
\text { Teak }\end{array}$} & $577 \pm 65^{1}$ & $4.39 \pm 0.48^{1}$ & $0.39 \pm 0.06$ & $3.69 \pm 0.73$ & $17.75 \pm 2.38$ & $3.37 \pm 0.46$ \\
plantation & $314 \pm 60$ & $1.16 \pm 0.38$ & $0.38 \pm 0.18$ & $1.93 \pm 0.44$ & $11.79 \pm 4.66$ & $2.25 \pm 0.84$ \\
t-value & $*$ & $* *$ & $\mathrm{NS}$ & $\mathrm{NS}$ & $\mathrm{NS}$ & $\mathrm{NS}$ \\
\hline
\end{tabular}

$1=$ standard error $\quad \mathrm{NS}=$ not significant at either $5 \%$ or $1 \%$ level

$* \quad=$ significant at $5 \%$ level $* *=$ significant at $1 \%$ level $\mathrm{n}=$ sample size

Table III. Nutrient concentrations in litter components of natural forest and teak plantation in Akure forest reserve

\begin{tabular}{|c|c|c|c|c|c|c|c|c|c|c|c|}
\hline \multirow[t]{2}{*}{ Period } & \multirow[t]{2}{*}{ Component } & \multicolumn{2}{|c|}{$\mathrm{N}$} & \multicolumn{2}{|c|}{$\mathrm{P}$} & \multicolumn{2}{|c|}{$\mathrm{K}$} & \multicolumn{2}{|c|}{$\mathrm{Ca}$} & \multicolumn{2}{|c|}{ Mg } \\
\hline & & 1 & 2 & 1 & 2 & 1 & 2 & 1 & 2 & 1 & 2 \\
\hline February- & Leaf & 1.08 & 0.28 & 0.08 & 0.04 & 1.08 & 0.34 & 4.24 & 2.80 & 0.92 & 0.40 \\
\hline \multirow[t]{2}{*}{ April } & Twig & 0.73 & 0.27 & 0.17 & 0.002 & 0.16 & 0.05 & 1.68 & 0.73 & 0.31 & 0.16 \\
\hline & Reproductive & 0.51 & 0.33 & 0.04 & 0.04 & 1.10 & 0.72 & 0.87 & 1.83 & 0.20 & 0.40 \\
\hline May- & Leaf & 0.97 & 0.06 & 0.06 & 0.13 & 0.68 & 0.43 & 3.38 & 3.62 & 0.55 & 0.83 \\
\hline \multirow[t]{2}{*}{ August } & Twig & 0.19 & 0.28 & 0.03 & 0.03 & 0.29 & 0.23 & 3.52 & 1.44 & 0.65 & 0.27 \\
\hline & Reproductive & 1.63 & 0.17 & 0.01 & 0.10 & 0.61 & 1.19 & 2.13 & 4.12 & 0.40 & 0.92 \\
\hline September- & Leaf & 0.79 & 0.17 & 0.05 & 0.07 & 0.53 & 0.43 & 3.57 & 3.80 & 0.69 & 0.66 \\
\hline \multirow[t]{2}{*}{ December } & Twig & 0.48 & 0.14 & 0.04 & 0.05 & 0.21 & 0.37 & 5.30 & 4.20 & 1.00 & 0.77 \\
\hline & Reproductive & 0.47 & 0.03 & 0.01 & 0.04 & 1.41 & 0.60 & 1.04 & 1.14 & 0.19 & 0.23 \\
\hline January- & Leaf & 0.65 & 0.37 & 0.08 & 0.05 & 0.53 & 0.50 & 4.02 & 1.82 & 0.71 & 0.36 \\
\hline \multirow[t]{2}{*}{ April } & Twig & 0.03 & 0.14 & 0.06 & 0.01 & 0.27 & 0.05 & 3.37 & 1.51 & 0.69 & 0.26 \\
\hline & Reproductive & 0.72 & 0.43 & 0.08 & 0.05 & 0.52 & 0.53 & 3.50 & 0.78 & 0.66 & 0.09 \\
\hline May- & Leaf & 1.04 & 1.49 & 0.09 & 0.05 & 0.83 & 0.35 & 2.96 & 2.53 & 0.58 & 0.48 \\
\hline \multirow[t]{2}{*}{ August } & Twig & 0.15 & 0.25 & 0.01 & 0.06 & 0.25 & 0.38 & 2.72 & 2.15 & 0.55 & 0.40 \\
\hline & Reproductive & 0.33 & 0.39 & 0.04 & 0.06 & 0.72 & 0.79 & 0.81 & 0.95 & 0.12 & 0.17 \\
\hline September- & Leaf & 0.97 & 0.34 & 0.05 & 0.15 & 0.37 & 0.49 & 2.15 & 3.63 & 0.41 & 0.67 \\
\hline \multirow[t]{2}{*}{ December } & Twig & 0.40 & 0.31 & 0.04 & 0.01 & 0.67 & 0.35 & 3.26 & 1.12 & 0.57 & 0.38 \\
\hline & Reproductive & 0.54 & 0.08 & 0.03 & 0.08 & 0.49 & 0.71 & 2.17 & 3.35 & 0.55 & 0.71 \\
\hline \multirow[t]{3}{*}{ January } & Leaf & 0.24 & 0.25 & 0.09 & 0.09 & 1.56 & 0.24 & 2.50 & 3.19 & 0.45 & 0.65 \\
\hline & Twig & 0.17 & 0.34 & 0.04 & 0.01 & 0.71 & 0.12 & 1.11 & 1.13 & 0.21 & 00.21 \\
\hline & Reproductive & 0.39 & 0.25 & 0.001 & 0.003 & 0.001 & 0.08 & 0.001 & 2.67 & 0.003 & 0.83 \\
\hline
\end{tabular}

$1=$ Natural forest

2 = TeakPlantation 
Table IV. Annual nutrient in litter components (kg/ha) of the natural forest and teak plantation of Akure reserve

\begin{tabular}{|c|c|c|c|c|c|c|c|}
\hline \multirow[t]{2}{*}{ Year } & \multirow[t]{2}{*}{ Vegetation } & \multirow[t]{2}{*}{ Litter part } & \multicolumn{3}{|c|}{ Nutrient } & \multirow[b]{2}{*}{ Сa } & \multirow[b]{2}{*}{$\mathrm{Mg}$} \\
\hline & & & $\mathrm{N}$ & $\mathrm{P}$ & K & & \\
\hline & \multirow[t]{4}{*}{ Natural forest } & Leaf & $41.87 \pm 0.58^{1}$ & $3.52 \pm 0.05$ & $34.51 \pm 0.63$ & $173.32 \pm 2.62$ & $33.30 \pm 0.55$ \\
\hline & & Twig & $2.92 \pm 0.07$ & $0.47+ \pm 0.01$ & $1.62 \pm 0.03$ & $26.47 \pm 0.54$ & $4.98 \pm 0.10$ \\
\hline & & Reproductive & $1.60 \pm 0.04$ & $0.06 \pm 0.003$ & $1.90 \pm 0.07$ & $2.57 \pm 0.06$ & $0.52 \pm 0.01$ \\
\hline & & Total & $46.39 \pm 0.61$ & $4.05 \pm 0.06$ & $38.06 \pm 0.67$ & $202.36 \pm 2.49$ & $38.80 \pm 0.53$ \\
\hline & \multirow[t]{4}{*}{ Teak Plantation } & Leaf & $6.50 \pm 0.25$ & $1.99 \pm 0.05$ & $12.92 \pm 0.38$ & $91.76 \pm 2.38$ & $16.70 \pm 0.42$ \\
\hline & & Twig & $1.00 \pm 0.03$ & $0.09 \pm 0.003$ & $0.78 \pm 0.02$ & $7.65 \pm 2.20$ & $1.45 \pm 0.04$ \\
\hline & & Reproductive & $2.83 \pm 0.08$ & $0.55 \pm 0.02$ & $9.00 \pm 0.41$ & $24.09 \pm 10.04$ & $5.26 \pm 0.23$ \\
\hline & & Total & $10.33+0.29$ & $2.63 \pm 0.04$ & $22.70 \pm 0.03$ & $123.50 \pm 2.21$ & $23.41 \pm 0.40$ \\
\hline & \multirow[t]{4}{*}{ Naturalforest } & Leaf & $57.70 \pm 0.87$ & $5.06 \pm 0.07$ & $47.89 \pm 1.15$ & $204.47 \pm 2.62$ & $37.86 \pm 0.46$ \\
\hline & & Twig & $1.10 \pm 0.03$ & $0.26 \pm 0.01$ & $2.47 \pm 0.05$ & $183.31 \pm 0.28$ & $3.97 \pm 0.07$ \\
\hline & & Reproductive & $0.19 \pm 0.01$ & $0.02 \pm 0.0003$ & $0.20 \pm 0.005$ & $1.09 \pm 0.03$ & $0.16 \pm 0.005$ \\
\hline & & Total & $58.99 \pm 0.94$ & $5.34 \pm 0.05$ & $50.56 \pm 1.14$ & $223.87 \pm 2.68$ & $41.99 \pm 47$ \\
\hline & \multirow[t]{4}{*}{ Teak plantation } & Leaf & $15.73 \pm 0.68$ & $6.22 \pm 0.32$ & $21.07 \pm 1.01$ & $151.73 \pm 7.52$ & $29.11 \pm 1.38$ \\
\hline & & Twig & $0.55 \pm 0.01$ & $0.06 \pm 0.001$ & $0.53 \pm 0.01$ & $3.44 \pm 0.05$ & $0.73 \pm 0.01$ \\
\hline & & Reproducive & $1.16 \pm 0.04$ & $0.17 \pm 0.004$ & $2.02 \pm 0.16$ & $4.28 \pm 0.10$ & $0.76 \pm 0.02$ \\
\hline & & Total & $17.44 \pm 0.67$ & $6.45 \pm 0.31$ & $23.62 \pm 0.99$ & $159.45 \pm 7.64$ & $30.60 \pm 1.37$ \\
\hline
\end{tabular}

greatest percentage concentration of nutrients while the twig had the least in both ecosystems. Concentration of nutrients did not follow a specific pattern.

\section{Amount of nutrients in litterfall}

The amount of each nutrient depends on two factors- the concentration of the element in the litter part under consideration and the mass of the part itself. Generally, Ca dominated the other elements in litterfall at the two sites, $202 \mathrm{~kg}$ and $124 \mathrm{~kg}$ of Ca was produced in a hectare of land under the forest and plantation respectively in the first year while $224 \mathrm{~kg}$ and $159 \mathrm{~kg}$ of the same element was produced in the same area of land of the natural forest and plantation respectively in the second year (Table IV). On annual basis, the elements stood at $53 \mathrm{~kg}$ and $14 \mathrm{~kg} \mathrm{~N}, 5 \mathrm{~kg}$ and $4 \mathrm{~kg} \mathrm{P}, 44 \mathrm{~kg}$ and $23 \mathrm{~kg}$ $\mathrm{K}, 213 \mathrm{~kg}$ and $141 \mathrm{~kg} \mathrm{Ca}$ and $40 \mathrm{~kg}$ and $27 \mathrm{~kg} \mathrm{Mg}$ in the natural forest and plantation respectively. Only $\mathrm{N}$ was statistically significant at $1 \%$ probability level (Table II). Differences in the mean values of other elements were minor.

\section{Litter mass}

The litter collected under the natural forest $\left(6,688 \mathrm{~kg} / \mathrm{ha}^{-1}\right.$ $\left.\mathrm{yr}^{-1}\right)$ was about twice that of the under the plantation $(3,774$ $\mathrm{kg} / \mathrm{ha}^{-1} \mathrm{yr}^{-1}$ ). Data on annual litterfall and nutrient content in this study were compared with results of similar studies in other tropical forests (Table V). The dry matter content values of this study's variation from the results of similar studies may be due to differences in location, edaphic factors, spacing, human activities, trees species, their sizes and age. All these factors had been known to influence the amount and volume of liiterfall. (Ojo, 2005). For instance, Weaner et al., (1987) reported that trees of greater timber size tend to have more litter in Puerto Rico, and Lugo (1992) also reported that variation in spatial distribution of litter in mass occurred also in Puerto Rico due to location. Songwe (1984) reported a massive litterfall in a mature tropical rainforest in Cameroon due to that type of forest while Nwoboshi (1981) observed a relatively large litterfall in a 25-year-old teak plantation in Ibadan, Nigeria probably due to the number and age of tree in the plantation. Spacing of trees had also been observed to affect litter mass. For instance, Ola-Adams and Egunjobi (1992) observed variation in the amount of litterfall in relation to teak trees spacing in Ibadan, Nigeria.

Ecological reaction to seasonal changes had been known to affect the timing of peaks and termal distribution of litter mass. The plantation had more litterfall at the on - set of the dry season probably due to such ecological reactions. The dry season brought along with it a massive litterfall. This was similar to Lugo (1992) study in Puerto Rico where the plantation reacted more quickly to seasonal changes than the 
Table V: Comparison of quantites of litterfall and nutrients (kg/ha/yr) under different tropical forests

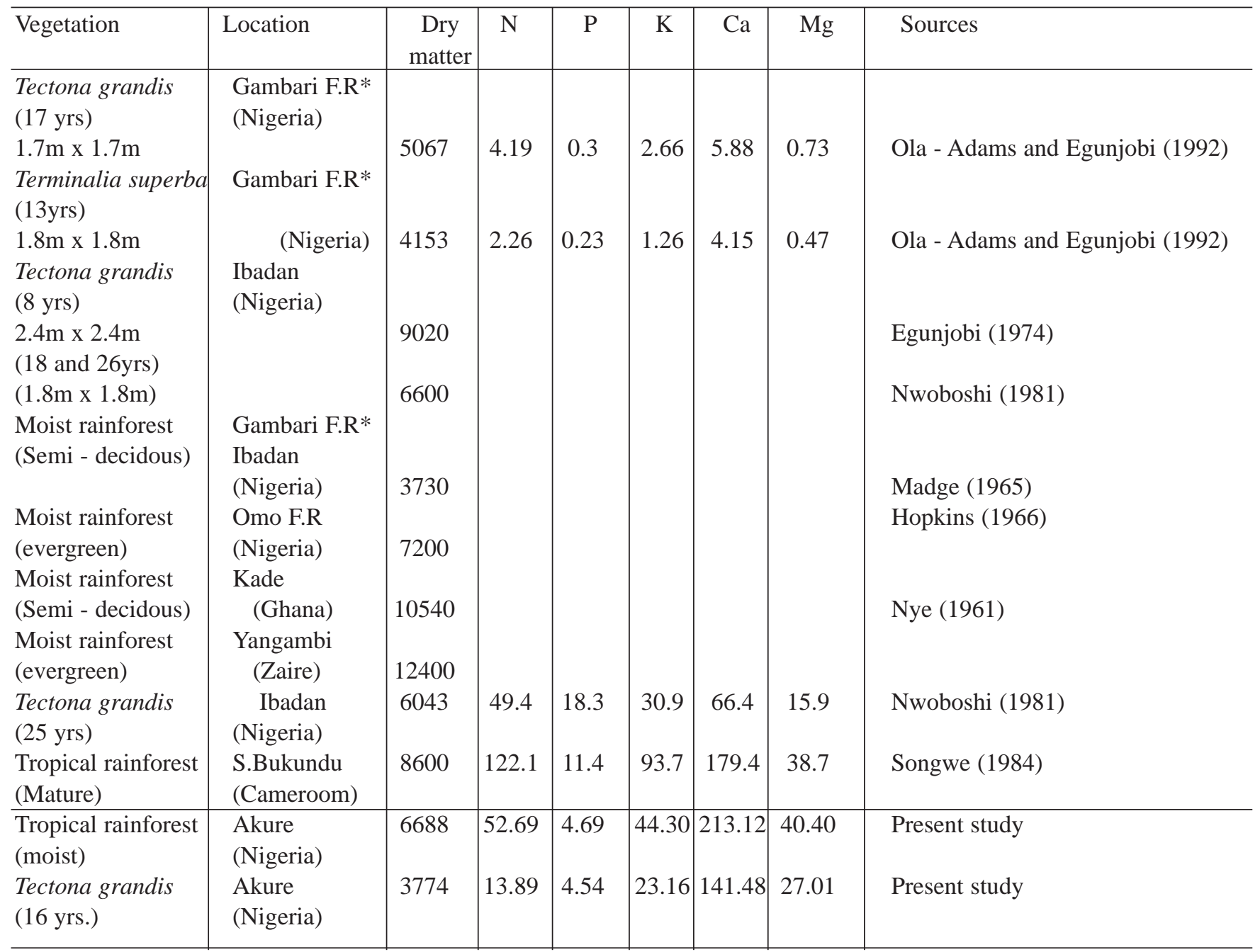

$\mathrm{FR}=$ forest reserve

adjacent secondary forest in terms of peak litterfall. The fact that the two ecosystems had their litter peaks in the dry season confirmed an earlier report in a similar study in Australia by O Connell and Menage (1985) that litter peaks are related to water deficit. This deficit is likely to be severe during the dry season.

\section{Changes in litter nutrient}

The natural rainforest seemed to have contributed more nutrient to the nutrient recycling process. This is probably due to the volume of litterfall. Even though there was a significant difference in the values of litterfall at the two sites, only $\mathrm{N}$ was significant at $1 \%$. Differences in values of other elements were minor. The significant value of $\mathrm{N}$ may be due to the presence of leguminous trees in the heterogenous rainforest. Most leguminous plants are known to fix nitrogen directly from the atmosphere. The non - significant nature of other elements showed that the plantation had a more nutrient immobilization in its litter especially as canopy closed and therefore eliminated any level of nutrient in - take difference as according to Nwoboshi (1981) teak takes much of the nutrient of its site.

The results of this study showed that the replacement of a mature tropical high forest with a fast growing monoculture plantation of teak led to a drop in the litter mass but did not adversely affect the level of nutrients. This showed that the replacement of the natural secondary rainforest was not an 
impediment to the ecosystem litter nutrient status. However, care should be taken to consider establishing plantation in degraded and marginal ecosystems rather than clearfelling mature tropical species - rich high forest for such purpose. This will help much in the maintenance of such forests to sustain their biodiversity.

\section{Acknowledgement}

We wish to express our appreciation to the authority of the Forestry Research Institute of Nigeria at Ibadan for allowing us to use its Strict Nature Reserve, SNR and the Government of Ondo State of Nigeria for the same purpose in her teak plantation for this study in Akure forest reserve.

\section{References}

Egunjobi, J. K. (1974). Litter fall and mineraliszation in a teak, Tectonia grandis, stand. OIKOS, 25: 222-226.

Fagbenro J. A and Onweluzo B. S. K. (1976). Soil Studies in Akure Forest Reserve Paper presented at the 7th Annual Conference of the Forestry Association of Nigeria Nov. 20 - 27, 1976Kano Nigeria 27p.

Fagbenro J. A., Orimayegun, S. O., Aluko A. P. and Daramola D. S. (1976). Assessment of biomass production, coppicing and nitrogen fixing capabilities of some nitrogen fixing legume trees in two Nigeria soils. A paper presented at a conference held at the Forestry Research Institute of Nigeria, Ibadan 23p.

FAO/UNESCO (1977). Soil map of the would 1:5,000,000. Vol. VI Africa. UNESCO, Paris.

Hopkins B. (1966). Vegetation of the Olokemeji Forest Reserve, Nigeria IV: The litter and soil with special reference to their seasonal changes. Journal of Ecology 54: 689-703.

Madge, D. S. (1965). Leaf fall and litter disappearance in a tropical forest. Pedobiologia 5: 273-288.

Nwoboshi L. C. (1981). Potential impacts of some harvesting option on nutrient budgets of a Gmelina arborea pulpwood exosystem in Nigeria. Pp. 212 - 217. In: ILFRO symposium on forest site and continous produc- tivity. Ballard, R. and Gessels, S.P. (Eds). USDA Forest Service, Portland, Oregon, USA.

Nye P. H. (1961). Organic matter and nutrient cycles under moist tropical forest. Plant and Soil. 13: 333-346.

O' Connell A. M. and Menage P. M. A (1992). Litterfall and nutrient cycling in Kari (Eucalytus diversicolor, F. Muell) forest in relation to stand age. Aust J. Ecol. 7(1): 49- 62.

O' Connell A. M. and Sankaran K.V. (1997). Organic accretion, decomposition and mineralization. Pp. 443 - 573, In: Management of soil nutrient and water in tropical plantation forest. Nambiar, E. K. S and Brown, A.G (Eds). ACIAR Monograph No. 43 (XII).

Oguche F. A. (2002). Evaluation of phytotoxic effects of Gliricidia sepium and Acacia auriculiformis leaf leachate and mulch on germination and early growth of maize (Zea mays L.) M. Agric. Tech. Thesis. Federal University of Technology, Akure, Nigeria. 54p.

Ojo A. F. (2005). Organic matter and nutrient dynamics of the natural rainforest and teak plantation in Akure forest reserve, Nigeria. Unpublished $\mathrm{PhD}$ Thesis, Federal University of Technology, Akure, Nigeria. 130p.

Okeke A. I and Omaliko, C. P. E. (1992). Leaf litter decomposition and carbon dioxide evolution in some Agroforestry fallow species in southern Nigeria. Forest Ecology and Management, 50: 103 - 116.

Ola - Adams, B. A. and Egunjobi, J. K. (1992). Effect of spacing on litterfall and nutrient contents of Tectona grandis and Terminalia superba, Afr. J. Eco 30: 18 - 32.

Ola-Adams B. A. and Hall J. B. (1987). Soil-plant relations in a natural forest inviolate plot at Akure, Nigeria. Journal of Tropical Ecology 3: 57-74.

Shaw M. W. (1968). Factors affecting the natural vegetation of sessile oak in North Wales: II Acorn losses and regeneration under field conditions. Ecol. 56: 647 - 660

Songwe N. C. (1984). Litter production and decomposition in a tropical rainforest southern Bukundu Forest 
Reserve, Comeroon. Unpublished PhD Thesis, University of Ibadan, Ibadan, Nigeria. 256p.

Swift M. J. and Anderson J. M. (1989). Decomposition. Pp. 547- 569. In: Tropical rainforest ecosystem'. Ecosystem of the world. Lieth, A. and Wenger, M. J. A. (Eds.). Elsevier, Amsterdam.

Thornthwaite C. W. (1948). An approach towards a national classification of climate, Geographical Review 38: 35- 54 .
Upadhay, B. P. and Singh J. S. (1989). Pattern of nutrient immobilization and release in decomposing forest litter in Central Hamalaya, India. Journal of Ecosystem 77: $127-146$.

Weaner, P. L., Bindsay, R. A. and Lugo A. E. (1987). Soil organic matter in secondary forests in Puerto Rico. Biotropical 19(1): 17 - 23.

Received : September 02, 2009;

Accepted : Febuary 25, 2010 